\title{
TOKOH PEMIKIR MERCANTILISME DAN PENGARUHNYA TERHADAP PERUBAHAN SOSIAL MASYARAKAT
}

DEWI (90100118101)

EKONOMI ISLAM C 2018

Merkantilisme adalah sebuah paham perdagangan atau orang-orang yang gemar berdagang yang berkembang pada abad ke-16 sampai abad ke-18 di Negara Eropa Barat. Merkantilisme merupakan suatu paham yang menyatakan bahwa kesejahteraan suatu Negara ditentukan oleh banyaknya logan mulia (emas dan perak) yang dimiliki oleh negara tersebut. Untuk mempertahankann dan mempopulerkan sistem ini maka konsep merkantilisme diajarkan di sekolah-sekolah eropa pada saat itu hingga abad ke-18. Dalam perkembangannya, sistem ini menjelma menjadi kapitalisme yang digunakan hingga sekarang. Negara-negara merkantilisme pada saat itu adalah inggris, prancis, spanyol, dan portugis. Sistem ekonomi merkantilisme mulai menghilang pada akhir abad ke-18 yang ditandai dengan mulai munculnya teori-teori ekonomi baru. Pada masa perkembangan pemikiran ekonomi merkantilisme, sistem pemikiran ekonomi Islam pada masa ini menjadi stagnan. Hal ini dikarenakan beberapa para pemikir ekonomi Islam mengatakan bahwa pintu ijtihad telah tertutup karena mereka menganggap kehidupan ini sudah baik sehingga tidak perlu lagi untuk memperbaikinya. Tokoh-tokoh pemikir merkantilisme adalah:

1. Jean Bodin (1530-1596)

Jean Bodin lahir di Angers, Prancis dan meninggal pada bulan Juni 1596 di Laon. Jean Bodin merupakan seorang ilmuwan yang pertama menyajikan teori tentang uang dan harga secara sistematis. Menurutnya, bertambahnya uang yang diperoleh dari perdagangan luar negeri dapat menaikkan harga barang. Naiknya barang-barang ini tentunya dipengaruhi oleh beberapa hal. Pertama, bertambahnya logam mulia seperti emas dan perak. Kedua, praktik monopoli. Ketiga, jumlah barang dalam Negeri menjadi langkah karena sebagian di ekspor ke luar negeri. Keempat, kehidupan yang mewah oleh para bangsawan dan raja. Kelima, turunnya nilai mata uang logam karena isi karat di dalamnya dikurangi.

2. Thomas Mun (Inggris 1571-1641)

Thomas Mun adalah seorang saudagar kaya yang lahir dari Inggris tahun 1571. Menurutnya, kemakmuran suatu negara ditentukan oleh sumber pendapatannya yang 
diperoleh dari perdagangan luar negeri. Ia juga berpendapat bahwa nilai ekspor haruslah lebih besar dibandingkan dengan impor.

\section{Jean Baptiste Colbert (Prancis 1619-1683)}

Jean Baptiste Colbert lahir di Reims, Perancis pada tanggal 29 Agustus 1619 dan meninggal pada tanggal 6 september 1683. Ia bukanlah ahli ekonomi, melainkan pejabat Negara Perancis dengan kedudukan sebagai menteri utama di bidang ekonomi dan keuangan dalam pemerintahan Raja Louis XIV. Pada masa ini, sumber utama kemakmuran negara adalah dengan perdagangan luar negeri. Dalam praktik ekonomi, banyak terjadi aliansi antara para saudagar dengan penguasa. Kaum saudagar disini memperkuat dan mendukung kedudukan dari penguasa. Penguasa pun memberikan bantuan dan perlindungan berupa monopoli, proteksi, dan keistimewaan-keistimewaan lainnnya. Pada abad inilah Eropa dianggap sebagai zaman kapitalisme komersial yang kadangkala disebut kapitalisme saudagar (merchant capitalism) karena kaum saudagarlah yang memegang kendali perekonomian.

4. Sir William Petty (Inggris 1623-1687)

Sir William Petty lahir pada tanggal 26 Mei 1623 dan meninggal pada tanggal 16 Desember 1687. iadalah salah seorang ekonom, ilmuwan dan filsuf Inggris, anggota parlemen Inggris dan juga merupakan anggota piagam Royal Society. Pemikirannya tentang ekonomi bahwa ekonomi dan politik saling berkaitan satu sama lain dan menurutnya, pekerja (labor) jauh lebih penting dari sumber daya tanah (Land). Bagi Petty, bukan jumlah hari kerja yang menentukan nilai suatu barang, melainkan biaya yang diperlukan untuk menjaga agar para pekerja tersebut dapat tetap bekerja. Petty juga menuangkan pemikirannya tentang teori uang, bahwa uang itu harus dimiliki secukupnya saja karena jika uang yang dimiliki terlalu banyak maka akan mendatangkan kemudharatan. Alasannya karena dengan uang yang banyak bisa menimbulkan adanya monopoli, orang tertentu menguasai perekonoian, dan bisa orang yang mempunyai banyak uang bertidak bebas (Ubaid Al Faruq dan Edi Mulyanto, 2017)

5. David Hume (Skotlandia 1711-1776)

Pemikiran ekonomi oleh David Hume dituangkan dalam salah satu karyanya yang berjudul "of the balance of trade" yang membahas tentang harga yang sebagian dipengaruhi oleh jumlah barang dan sebagian lagi ditentukan oleh jumlah uang. Dalam teorinya, ia berpendapat bahwa keadilan sangat penting dalam suatu negara karena ketidakadilan akan memperlemah Negara. Dalam teorinya ia juga membahas hubungan antara neraca 
perdagangan dengan jumlah uang dan tingkat harga barang-barang umum pada suatu negara. Sistem Islam sangat mendorong harga yang adil dengan mendorong persaingan pasar yang sempurna. Untuk memenuhi harga yang adil perlu adanya moralitas (fair play), kejujuran (honesty), keterbukaan (transparancy) dan keadilan (justice) serta menghindari segala macam bentuk spekulasi (Idris Parakkasi dan Kamiruddin, 2018)

Pengaruh merkantilisme bagi perubahan sosial masyarakat adalah: pertama, secara tidak langsung merkantilisme merupakan cikal bakal dari ekonomi kapitalisme yang berlaku hingga sekarang ini, sistem ekonomi merkantilisme pada saat itu mendorong terjadinya revolusi besar seperti revolusi amerika dan prancis. Hal ini dikarenakan karena adanya monopoli dagang dan penarikan pajak yang menyengsarakan rakyat. Dalam bidang ekonomi, konsep merkantilisme yang berkembang menjadi kapitalisme telah mendorong terjadinya revolusi industri di Inggris. Kedua, meskipun secara geografis, indonesia tidak berada di daratan Eropa, namun kebijakan merkantilisme juga berpengaruh bagi bangsa Indonesia. Hal ini disebabkan pada saat itu wilayah Indonesia merupakan bagian dari koloni atau daerah jajahan bangsa Eropa. Sebagai negara jajahan, Indonesia pada saat itu dipaksa untuk memenuhi kebutuhan Negara induk. Di bawah pemerintah VOC dan Belanda, saat itu diterapkan sistem monopoli perdagangan khususnya untuk rempah-rempah dan beras. berbeda ketika Indonesia di bawah kekuasaan Inggris, pada saat itu diterapkan kebijakan sewah tanah. Inggris yang menjadikan Indonesia sebagai daerah penghasil bahan baku dan pemasaran bagi Inggris. Secara tidak langsung dengan adanya sistem sewa tanah, bangsa Indonesia ketika itu diperkenalkan dengan alat pembayaran uang. Sistem uang ini yang nantinya menggantikan sistem barter. 


\section{DAFTAR PUSTAKA}

Kamiruddin, I. P. (2018). Analisis Harga dan Mekanisme Pasar dalam Persfektif Islam. Laa Maysir, 5 (1): 107-120

Mulyanto, U. A. (2017). Sejarah Teori-Teori Ekonomi. Banten: Unpam Press 